\title{
Experiences on corrosion inhibitors for reinforced concrete
}

\author{
F. Bolzoni,* A. Brenna, G. Fumagalli, S. Goidanich, L. Lazzari, \\ M. Ormellese and MP. Pedeferri
}

\author{
Dipartimento di Chimica, Materiali e Ingegneria Chimica, "Giulio Natta", \\ Politecnico di Milano, Via Mancinelli 7 Milano Italia \\ *E-mail: fabio.bolzoni@polimi.it
}

\begin{abstract}
Corrosion of carbon steel reinforcement is the most important cause of premature failure on reinforced concrete structures. Prevention of corrosion is primarily achieved in the design phase by using high quality concrete and adequate cover. Additional prevention methods are adopted when severe environmental conditions occur or on structures requiring very long service life. Among these methods, corrosion inhibitors seem to offer a simple and cost effective prevention technique. They may be used both as a preventative techniques, if added to fresh concrete, and as a repair system, if applied on hardened concrete.

The performance of corrosion inhibitors for reinforced concrete structures affected by chloride induced and carbonation corrosion has been studied at PoliLaPP, Laboratory of Corrosion of materials "P. Pedeferri" of the Department of Chemistry, Materials and Chemical Engineering "G. Natta", Politecnico di Milano, in the last 15 years.

Organic commercial admixed corrosion inhibitors delayed the occurrence of chloride induced corrosion. This result is related to two effects: reduction of the rate of chloride transport into concrete and increase of the critical chloride threshold.

Commercial migrating corrosion inhibitors (MCI) are able to delay time-to-corrosion of passive rebars in concrete subjected to chlorides ponding; this effect is mainly related to the reduction of chlorides diffusion coefficient. MCI can reduce the corrosion rate after corrosion initiation only in carbonated concrete, nevertheless efficiency is low and residual corrosion rate is not negligible.

Commercial MCI can penetrate into concrete mainly through capillary sorption but penetration depth is limited to $20 \mathrm{~mm}$.

The results obtained with nitrite-based inhibitor confirm literature data: the inhibitor is effective if the molar ratio $\left[\mathrm{NO}_{2}^{-}\right] /\left[\mathrm{Cl}^{-}\right]$is higher than $0.5-0.6$; in carbonated concrete, due to insufficient amount of inhibitor, no significant effect has been observed on corrosion rate.

Among the tested organic substances, compounds containing carboxylic group showed the best results solution tests: pitting potential, time-to-corrosion and critical chloride content are similar to those obtained with sodium nitrite. In concrete tests, only one amine and one amino acid showed good performance increasing the critical chlorides
\end{abstract}


threshold with respect to the reference condition. For carboxylate substances, a strong link was found between inhibiting properties and molecular structure.

Key words: rebar corrosion, admixed corrosion inhibitors, migrating corrosion inhibitors, nitrite based inhibitors, amines, carboxylates.

Received: September 16, 2014.

doi: $\underline{10.17675 / 2305-6894-2014-3-4-254-278}$

\section{Introduction}

Reinforcement corrosion is the most important cause of premature failure of reinforced concrete structures world-wide, and became of great interest at the end of 80 s and early $90 \mathrm{~s}$ of the last century. Steel reinforcements in concrete structures are in passive condition, promoted by the concrete alkalinity. Nevertheless, passivity can be destroyed and corrosion may occur, due to two main causes: $a$ ) carbonation of concrete, that is the reaction of atmospheric carbon dioxide with the cement paste; $b$ ) presence of chlorides at the carbon steel surface in a content higher than a critical value [1]. It is well known from the literature that the value of this threshold is influenced by different factors: $\mathrm{pH}$ of concrete pore solution, type of cement, oxygen availability and temperature, cement paste porosity at the interface rebar-concrete [1-4]. Critical chloride content is strongly influenced by electrochemical potential as well described by the "Pedeferri diagrams" for cathodic protection and prevention [5-7]. For comparison purposes, critical chloride threshold can be generally considered in the range $0.4-1 \%$ by cement weight [1].

It is well known that the life of a reinforced concrete structure, as far as corrosion is concerned, presents two distinct periods. In the first (the initiation phase) carbon dioxide or chlorides penetrate the concrete cover, reach the reinforcement and eventually depassivate the steel. In the second (the propagation phase) corrosion takes place in presence of oxygen and water (Tuutti's model). The propagation period end when a critical serviceability limit state is reached (e.g. cracking of concrete cover). The durability necessary for the requested service life can be obtained theoretically by increasing both the initiation period (e.g. acting on the quality of concrete or on the cover thickness), and the propagation time (e.g. controlling the factors which determine the corrosion rate, such as concrete resistivity). In general, the first action, which extends the initiation time, is more viable and reliable, and this is more evident in the case of chloride induced corrosion, due to the fact that localised corrosion rate can be very high and propagation time very short [1].

Prevention of corrosion is primarily achieved in the design phase by using high quality concrete and adequate cover. Additional prevention methods are adopted when severe environmental conditions occur or on structures requiring very long service life [1]. Among additional protection methods, corrosion inhibitors seem to be attractive because of low cost and easy handling, compared with other methods.

Corrosion inhibitors have been the subject of numerous studies in the past decades [8-10]. They are applied in various technical areas, including the construction industry. Corrosion inhibitors for steel reinforcement in concrete can increase either the initiation 
period (increasing the chloride threshold value or reducing chloride penetration) or propagation period, reducing corrosion rate [11]. From a practical point of view, inhibitors can be divided in two groups: products added to the fresh concrete for new structures (mixed in), and migrating inhibitors which can penetrate the hardened concrete and are proposed in rehabilitation [11-13].

Nitrite-based inhibitors (mixed-in) are considered the most effective products available in the market. Early studies dates back to the late 50's, while systematic investigation as additives to fresh concrete started later in the 60's in different countries (USSR, USA, Japan) and are commercially available since the 70's of the last century [14-19]. Nitrites act as a passivator due to its oxidising properties, and its inhibitive effectiveness is related to the $\left[\mathrm{NO}_{2}^{-}\right] /\left[\mathrm{Cl}^{-}\right]$molar ratio, that should be higher than $0.5-0.6$ to prevent corrosion [11]. Concerns are with their toxicity, solubility and possible increase of corrosion rate in case of low dosage or in the presence of cracks. Controversial results were obtained in severe conditions (presence of cracks in concrete cover, seawater) [20]. Under similar conditions, some commercial organic products showed low inhibition efficiency, too $[21,22]$.

Commercial organic inhibitors are available from 80's. As reported in the state of the art by Elsener [11], there is no agreement among the scientific community in defining the effectiveness of these inhibitors; conflicting results are reported [21-28]. Moreover, the chemical composition of the organic commercial inhibitors and the concentration of the inhibitive substances are not clearly known. No indication is given about the inhibitor dosage to prevent corrosion in relation to the chloride content, and no literature data provide values of critical chloride threshold in the presence of organic inhibitors.

Migrating corrosion inhibitors (MCI) for concrete structures were studied in the last 20 years. Proposed MCIs are both inorganic compounds (sodium-mono-fluoro-phosphate) $[28,29]$ and organic aqueous mixtures based on a volatile amine constituents and a non volatile ones, mainly a carboxylate compound or a P-containing compound [11, 23-25]. They are claimed to inhibit corrosion by penetrating concrete and adsorbing on the metal surface. There is some criticism regarding their application: there are doubt on migration ability [30], or the inhibitors may penetrate only in conditions (low concrete cover, less compact concrete) that favours penetration of aggressive agents too [25, 28]. Some authors stated that MCIs do not show a substantial improvement of the corrosion resistance of reinforcing steel embedded in concrete exposed to chlorides under immersion conditions $[12,31]$. However, some efficiency can be achieved in simulated pore solution. The reason of low inhibiting properties in concrete has been attributed to the fact that one of the inhibitor constituents does not reach the embedded steel, reacting with cement paste [32].

In the last 20 years there have been a lot of interest in studying new compounds able to prevent or stop corrosion, and in understanding the inhibition mechanism. Non commercial inhibitors, both inorganic and organic have been studied: both inorganic (zinc oxide, molybdates, borates, stannates) and organic compounds (benzoate and its 
derivatives, carboxylate ions, quaternary ammonium salts, citrate and amine-based substances) [11,33-39].

The performance of corrosion inhibitors for reinforced concrete structures has been studied at PoliLaPP, Laboratory of Corrosion of materials "P. Pedeferri" of the Department of Chemistry, Materials and Chemical Engineering "G. Natta", Politecnico di Milano, in the last 15 years on commercial corrosion inhibitors, both mixed in (nitrite based and organic) and migrating [40-44] and on organic compounds, mainly amines, carboxylates and amino acids [45-48].

The main results of these investigations were related to:

- the performance of commercial inhibitors (both mixed and migrating) and organic compounds

- the study of the mechanism of the inhibition

- the effect on the service life of reinforced concrete structures.

Most of the results are referred to chloride induced corrosion; nevertheless, also some results about carbonation induced corrosion has been got for commercial inhibitors.

\section{Experimental}

The research on corrosion inhibitors has been carried out in different phases through more than 15 years. Different research projects has been carried out:

- from 1997 to 2001 commercial corrosion inhibitors (mixed-in) available on market in 1997 were tested in concrete with W/C ratio equal to 0.5 and curing time 7 days (Series A) [40];

- from 2000 to 2006 commercial corrosion inhibitors (mixed-in and migrating) available on market in 2000 were tested in concrete with an higher W/C ratio, equal to 0.6 and curing time 28 days (Series B) [41-43].

- from 1999 to 2011 pure organic compounds have been studied, both in solution and in concrete (Series C) [45-48].

\subsection{Concrete}

Concrete was manufactured for the different research project according to Table 1 with CEM II A/L 42,5R (European standard CEN ENV 197/1 [49]) and limestone aggregates (12 mm maximum diameter).

Series A: water/cement ratio (W/C) equal to 0.5 , curing 7 days at $20^{\circ} \mathrm{C}$ and $95 \%$ relative humidity.

Series B and C: W/C ratio equal to 0.6 or 0.65 , and $1.770 \mathrm{~km} / \mathrm{m}^{3}$ of limestone aggregates. An acrylic super-plasticizer $(0.6 \%$ by cement weight) was added to concrete mixture. Curing 2 days in the mould, until 28 days in a wet environment ( $95 \% \mathrm{RH})$.

Compressive strength were measured on cubic specimens after 28 days of curing.

For each condition, reinforced concrete specimens were cast for electrochemical measurements, while chloride content was measured also on cubic plain concrete specimens. 
Inhibitors in the added dosage do not reduce significantly the mechanical properties nor the workability (Table 1).

Table 1. Concrete mixture proportion and mechanical properties.

\begin{tabular}{|c|c|c|c|c|c|c|}
\hline & & Series A1 & Series A2 & Series B1 & Series B2 & Series C \\
\hline Cement content & $\mathrm{kg} / \mathrm{m}^{3}$ & 300 & 400 & 367 & 338 & 367 \\
\hline Water/Cement ratio & & 0.5 & 0.5 & 0.6 & 0.65 & 0.6 \\
\hline Aggregate type & & limestone & limestone & limestone & limestone & limestone \\
\hline Aggregate content & $\mathrm{kg} / \mathrm{m}^{3}$ & 2000 & 1851 & 1770 & 1790 & 1770 \\
\hline Plasticizer & $\mathrm{kg} / \mathrm{m}^{3}$ & 4.5 & 6.6 & 2.2 & & 2.2 \\
\hline Slump & $\mathrm{mm}$ & 160 & 160 & 190 & & $150-210$ \\
\hline Curing time $(95 \% \mathrm{RH})$ & days & 7 & 7 & 28 & 28 & 28 \\
\hline Compressive strength ${ }^{\text {[a] }}$ & $\mathrm{MPa}$ & $46-47$ & 46 & $40-43$ & 30 & $36-40$ \\
\hline
\end{tabular}

\subsection{Commercial corrosion inhibitors}

Mixed-in commercial corrosion inhibitors (available on market in 1997) were added to concrete mixture according to producers recommendations. Three organic products and one nitrite-based product were considered. Dosages are reported in Table 2. For comparison purposes, specimens without inhibitors were cast [41]. The same four commercial corrosion inhibitors (but available on market in 2000) were added to the concrete mixture in the recommended dosages for series B, as reported in Table 2 [40, 43]. Corrosion inhibitors of these two series although nominally identical may have different chemical composition since they were bought in 1997 and 2000, respectively.

Table 2. Commercial corrosion inhibitors dosages.

\begin{tabular}{lcccc}
\hline & & Series A1 $^{[\mathbf{a}]}$ & Series A2 $^{[\mathbf{b}]}$ & Series B \\
\hline OCIA-1 (Liquid - amino-alcohols) & $\mathrm{L} / \mathrm{m}^{3}$ & 10 & 16 & 10 \\
OCIA-2 (Liquid - alkanolamines) & $\mathrm{L} / \mathrm{m}^{3}$ & 1.6 & 4 & 1.6 \\
OCIA-3 (Liquid - amine-esters) & $\mathrm{L} / \mathrm{m}^{3}$ & 5 & 7.5 & 5 \\
NIT (30 \% solution of calcium nitrite) & $\mathrm{kg} / \mathrm{m}^{3}$ & 7.5 & 20 & 10 \\
\hline
\end{tabular}

${ }^{[\mathrm{a}]}$ suggested by producers ${ }^{[\mathrm{b}]}$ maximum allowed

Two commercial migrating corrosion inhibitors (available on market in 2000) were tested: they were amines and alkanolamines based with phosphorous inorganic compounds in their mixture [42-44]. Applied dosages were increased 30\% approximately for the expected losses with respect the values suggested by manufacturers, i.e. $400 \mathrm{~g} / \mathrm{m}^{2}$ of 
concrete surface for inhibitor MIG-1, and $250 \mathrm{~g} / \mathrm{m}^{2}$ for inhibitor MIG-2. Number of applications depends on considered tests series. For the application the recommendations reported on the technical sheets were followed: concrete surfaces were carefully cleaned, dried, and after the inhibitors application, the specimens were closed for two weeks in a sealed container in order to avoid inhibitor evaporation. Then each specimen was exposed to its corrosive environment.

\subsection{Organic substances}

A first screening test (potentiodynamic test) was performed on about 80 organic compounds (mainly amines, amino-alcohols and carboxylates) in order to identify the best inhibiting substances [46].

The nine most effective compounds were 2 amines (dimethylethanolamine and triethylentetramine), 4 amino-acids (aspartate, asparagine, glutamate and glutamine) and 3 carboxylates compounds (tartrate, benzoate and EDTA). These organic substances contain in their molecular formula an aminic or a carboxylic group or both. These two functional groups are responsible for adsorption on the passive layer surface: the lone pair of the nitrogen atom and the delocalization of the electrical charge of the carboxylate anion $(-\mathrm{COO}-)$.

These 9 substances were tested in potentiostatic and free corrosion solution test and in concrete (series C). The dosage in solution was $1 \mathrm{~mol} / \mathrm{L}$, the dosage in concrete was $1 \%$ by cement weight with exception of sodium tartrate that was added $0.1 \%$, due to the effect on setting [47].

\subsection{Solution test}

Tests were performed on carbon steel samples machined from commercial reinforcement (characteristic yield strength $450 \mathrm{MPa}$ ), $10 \mathrm{~mm}$ in diameter and $40 \mathrm{~mm}$ long. Before starting the tests, specimens were sand-blasted and the extremities coated by self-adhesive tape to isolate the cross sections from the solution.

Tests were carried out in a synthetic pore solution obtained from a saturated $\mathrm{Ca}(\mathrm{OH})_{2}$ with $\mathrm{NaOH} 0.01 \mathrm{~mol} / \mathrm{L}(\mathrm{pH}$ 12.6). $\mathrm{NaCl}$ has been added in the case of solution containing chlorides.

A first screening test (potentiodynamic test) was performed on about 80 organic compounds $\mathrm{n}$ order to identify the best inhibiting substances. Potentiostatic polarisation and free corrosion tests have been carried out on the best 9 substances selected (Table 3); their dosage was $1 \mathrm{~mol} / \mathrm{L}$. For comparison purposes, tests with sodium nitrite $1 \mathrm{~mol} / \mathrm{L}$ and tests without any inhibitors (reference) were also performed.

Cyclic potentiodynamic polarisation test. E- $\log i$ curves has been measured to identify pitting potential $\left(E_{\mathrm{pit}}\right)$, repassivation potential $\left(E_{\mathrm{rep}}\right)$ and passivity range. Potentiodynamic tests were performed according to the Standard Test Method ASTM G61 [50]. Scanning rate was $1 \mathrm{~V} / \mathrm{h}$, starting from $-1.2 \mathrm{~V} \mathrm{SCE}$ in the anodic direction until $10 \mathrm{~mA}$ current was reached (corresponding to about $10 \mathrm{~A} / \mathrm{m}^{2}$ ), then reversing the potential 
scanning to the cathodic direction up to $-1.2 \mathrm{~V} \mathrm{SCE}$. Tests started $1 \mathrm{~h}$ after the immersion of the specimen in the solution.

Table 3. Analysed organic substances.

\begin{tabular}{|c|c|c|c|}
\hline \multirow{2}{*}{ Amines } & AM 1 & Dimethylethanolamine (DMEA) & $\left(\mathrm{CH}_{3}\right)_{2} \mathrm{~N}\left(\mathrm{OH} \mathrm{CH} \mathrm{CH}_{2}\right)$ \\
\hline & AM 2 & Triethylentetramine (TETA) & $\mathrm{NH}_{2}-\mathrm{CH}_{2} \mathrm{CH}_{2}-\left(\mathrm{NHCH}_{2} \mathrm{CH}_{2}\right)_{2}-\mathrm{NH}_{2}$ \\
\hline \multirow{4}{*}{ Amino acids } & AMAC 1 & Sodium Aspartate & $\mathrm{COOH}-\mathrm{NH}_{2}-\mathrm{CH}-\mathrm{CH}_{2}-\mathrm{COOH}$ \\
\hline & AMAC 2 & Asparagine & $\mathrm{COOH}-\mathrm{NH}_{2}-\mathrm{CH}-\mathrm{CH}_{2}-\mathrm{CONH}_{2}$ \\
\hline & AMAC 3 & Sodium Glutamate & $\mathrm{COOH}-\mathrm{NH}_{2}-\mathrm{CH}-\mathrm{CH}_{2}-\mathrm{CH}_{2}-\mathrm{COOH}$ \\
\hline & AMAC 4 & Glutamine & $\begin{array}{c}\mathrm{COOH}-\mathrm{NH}_{2}-\mathrm{CH}-\mathrm{CH}_{2}-\mathrm{CH}_{2}- \\
\mathrm{CONH}_{2}\end{array}$ \\
\hline \multirow{3}{*}{ Carboxylates } & CARB 1 & Sodium benzoate & $\mathrm{C}_{6} \mathrm{H}_{5}-\mathrm{COOH}$ \\
\hline & CARB 2 & Sodium tartrate & $\mathrm{HOOC}-(\mathrm{CHOH})_{2}-\mathrm{COOH}$ \\
\hline & CARB 3 & EDTA & $(\mathrm{HOOC})_{2}-\mathrm{N}-\mathrm{CH}_{2}-\mathrm{N}-(\mathrm{COOH})_{2}$ \\
\hline
\end{tabular}

Potentiostatic polarization tests. In potentiostatic tests, 13 carbon steel specimens have been placed in a $3 \mathrm{~L}$ cylindrical cell $(20 \mathrm{~cm}$ in diameter). Specimens have been polarized at $0 \mathrm{mV} \mathrm{SCE}$, using an activated titanium net-wire as counter-electrode placed in the bottom of the cell. The polarisation potential simulates the corrosion behaviour of carbon steel rebar in pristine concrete exposed to atmosphere. The current flowing in each sample has been monitored through a series of shunts. The solution was initially chlorides free: as soon as current density reached values typical of passive conditions (passive current density lower than $0.001 \mathrm{~A} / \mathrm{m}^{2}$ ), chlorides were periodically added every $80-90 \mathrm{~h}$ to the solution $(0.05,0.1,0.2$ up to $1.2 \mathrm{~mol} / \mathrm{L})$. Corrosion occurrence was revealed by increase in the current and confirmed by visual inspection.

Free corrosion tests. Three not polarised carbon steel specimens have been immersed in each test cell. During the first 15 days, solution was chlorides free. Then chlorides were periodically (each 15 days) added to the solution as follows: $0.05,0.1,0.2$ up to $0.4 \mathrm{~mol} / \mathrm{L}$. Free corrosion potential and corrosion rate have been monitored. For some compounds, also EIS was performed [45].

\subsection{Concrete tests}

Different series of concrete specimens were cast: series A and B with commercial corrosion inhibitors ( 3 organics and 1 nitrite-based product) and series $\mathrm{C}$ with organic substances.

For chloride induced corrosion specimens were of two types: chloride containing or without chlorides. The first type was exposed outdoor in Milano (Italia), while the second type were subjected to accelerated chlorides penetration, i.e. ponding cycles three week 
long: in the first week the upper surface of the concrete samples was wetted with a $3.5 \%$ sodium chloride solution, then for the next two weeks, samples were dried in laboratory.

In the case of carbonation induced corrosion the specimens were first exposed, after curing, to accelerated carbonation chamber (pure $\mathrm{CO}_{2}$ ) at room temperature and $65 \% \mathrm{RH}$. After they were exposed to atmospheric environment (Milano, Italia).

Concrete specimens. Concrete specimens $(160 \times 250 \times 70 \mathrm{~mm})$ for Series $A$ have been cast with a carbon steel rebar in each concrete specimen: $10 \mathrm{~mm}$ in diameter and $270 \mathrm{~mm}$ length. The ends of each rebar were covered by thermoretractil sheath, so that only a length of $170 \mathrm{~mm}$ was exposed to the concrete (Figure 1). Concrete cover was $20 \mathrm{~mm}$. Two AISI 304 stainless steel rebars $(10 \mathrm{~mm}$ in diameter) and an AISI 304 stainless steel wire $(1 \mathrm{~mm}$ diameter) were placed in concrete specimens for corrosion rate measurements. Three specimens for each condition were cast.

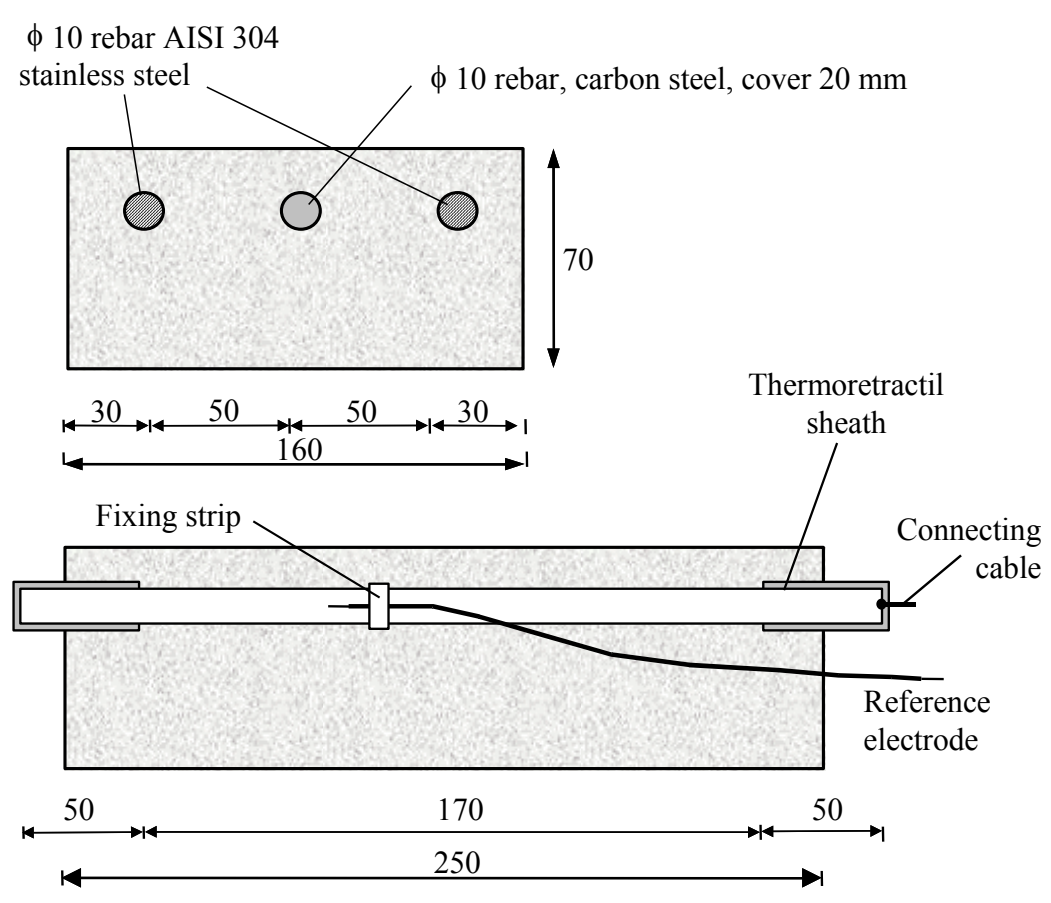

Figure 1

Concrete specimens $(200 \times 250 \times 50 \mathrm{~mm})$ for series $B$ and $C$ were cast with two carbon steel rebars $(10 \mathrm{~mm}$ in diameter and $290 \mathrm{~mm}$ length) in each concrete specimen (Figure 2). The ends of each rebar were coated, so that only a length of $210 \mathrm{~mm}$ was exposed to the concrete. Concrete cover was $20 \mathrm{~mm}$. A thin wire of mixed metal oxide activated titanium (MMO) was fixed near each rebar to be used as reference electrode and three AISI 304 stainless steel wires (2 $\mathrm{mm}$ in diameter) were embedded in the specimens and used as counter-electrode for corrosion rate measurements. Two specimens for each condition were cast.

Corrosion monitoring. Corrosion was monitored by potential measurements with respect to a saturated calomel reference electrode (SCE, $+244 \mathrm{mV} \mathrm{SHE}$ ) placed on the wet concrete surface [51], and by corrosion rate evaluation, obtained by means of linear 
polarization resistance technique [52, 53], applying a potential scan rate of $10 \mathrm{mV} / \mathrm{min}$ in the range $\pm 10 \mathrm{mV}$ with respect to the free corrosion potential. Mean corrosion rate, $i_{\text {corr }}$ $\left(\mathrm{mA} / \mathrm{m}^{2}\right)$ was evaluated by the Stern-Geary equation:

$$
i_{\text {corr }}=C / R_{\mathrm{p}}
$$

where $R_{\mathrm{p}}$ is the polarization resistance $\left(\Omega \cdot \mathrm{m}^{2}\right)$ and $C$ is assumed equal to $26 \mathrm{mV}$. For steel, current density $1 \mathrm{~mA} / \mathrm{m}^{2} \sim 1$. Since corrosion penetration lower than $1-2 \mu \mathrm{m} / \mathrm{y}$ can be considered negligible [1], polarization resistance value of about $20 \Omega \cdot \mathrm{m}^{2}$ is the threshold value below which corrosion is significant.
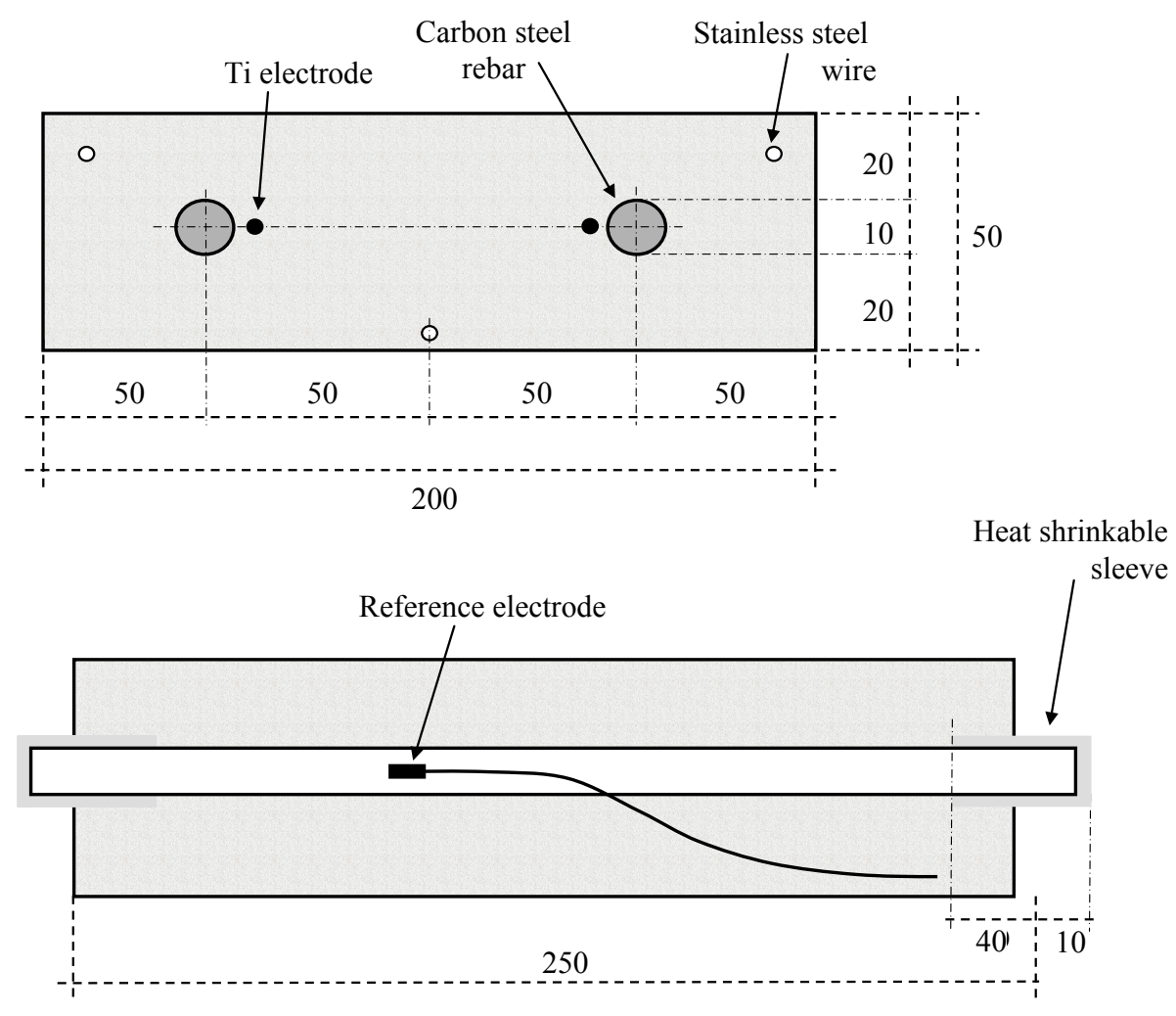

Figure 2

Some concrete specimens (series A) were broken at the end of the test. Rebars were extracted from concrete specimens for visual inspection and weight loss measurements. Weight loss has been estimated as the weight per unit length difference between rebars in contact with concrete, and uncorroded rebars protected by the sheath. Weight was measured by an analytical balance $(0.001 \mathrm{~g})$, and rebar length were measured by a comparator $(0.01 \mathrm{~mm})$.

In order to determine the chlorides profile, concrete cores (30 $\mathrm{mm}$ in diameter) were extracted at different time from concrete specimens. The cores were sliced; each slice was milled and then dissolved in nitric acid. The total chlorides content was evaluated by potentiometric titration with $\mathrm{AgNO}_{3} 0.1 \mathrm{~mol} / \mathrm{L}$. 


\section{Results and discussion}

The discussion of the results will be focused on the effect of corrosion inhibitor on the service life of reinforced concrete structure:

- delay of corrosion initiation

- reduction of corrosion rate, after corrosion initiation.

The results will be presented separately for commercial corrosion inhibitors and organic substances.

\subsection{Commercial corrosion inhibitors - admixed - chloride induced corrosion}

The monitoring of the potential and corrosion rate in concrete subjected to chloride ponding, as shown in Figure 3 for concrete series B, enable to highlight that the presence of mixed in inhibitors increases time-to-corrosion: in these tests, corrosion initiation is evidenced by a sudden decrease of the corrosion potential and a contemporary (more or less) increase of the corrosion rate. For the same series in Table 4 it is reported the number of the ponding cycle in which the corrosion initiation was detected: in concrete without inhibitors is observed the lowest time-to-corrosion while the most effective inhibitor is OCIA-1 (liquid aminoalcohols based): at the end of test on series B (after 86 ponding cycle, corresponding to more than 5 years) one rebar is still in passive condition. Only a slight effect was noticed in the presence of inhibitor OCIA-2. Inhibitor OCIA-3 has an intermediate behavior.

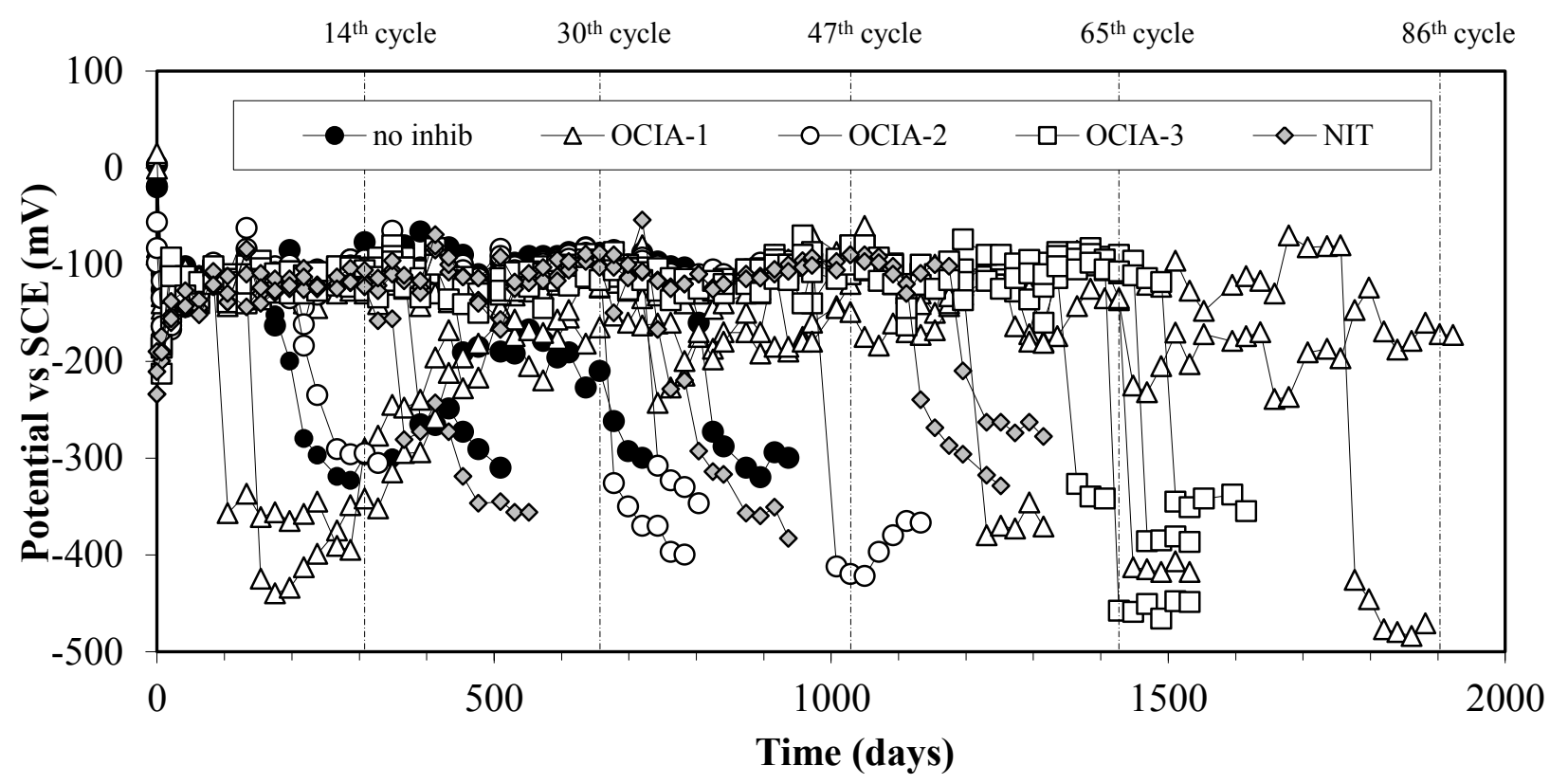

Figure 3. Free corrosion potential of rebars in specimen subjected to chloride penetration (series B) [43]. 
Table 4. Summary of the results of the ponding test on concrete series B.

\begin{tabular}{lccc}
\hline & $\begin{array}{c}\boldsymbol{T} \text { initiation } \\
\text { (cycle) }\end{array}$ & $\boldsymbol{D}\left(\mathbf{1 0}^{-8} \mathbf{c m}^{\mathbf{2} / \mathbf{s})}\right.$ & $\begin{array}{c}\text { Critical Cl } \\
\text { vs cement) }\end{array}$ \\
\hline No inhibitor & $10-38$ & $6.8-10$ & $0.5-1.2 \%$ \\
OCIA-1 & $56-87^{(*)}$ & $2.5-6.8$ & $1.1-1.8 \%$ \\
OCIA-2 & $12-46$ & $2-4.7$ & $0.7-1.3 \%$ \\
OCIA-3 & $62-69$ & $1.9-3.2$ & $1.4-2.6 \%$ \\
NIT & $21-56$ & $3.1-6.1$ & $1-2.3 \%$ \\
\hline
\end{tabular}

(*) corrosion did not initiate after 87 cycles for one rebar.

Nitrite-based inhibitor (NIT) effect is scattered: time-to-corrosion ranged from values similar to those measured in the absence of inhibitors to values slightly lower than those obtained in the presence of inhibitor OCIA-3.

In concrete series A (not shown here) the effect of organic corrosion inhibitors were more scattered. Nevertheless, the initiation time was increased and the best performance was shown by OCIA-1 [40].

The influence of inhibitors on initiation of corrosion may be related to an increase in the critical chloride threshold, as well as to a reduction of chloride penetration rate (as a reduction of chloride diffusion coefficient).

Chloride transport. Chlorides transport in concrete is due to the presence of different mechanisms: mainly diffusion and capillary sorption. Only for comparison purposes, experimental profiles may be interpolated using an analytical solution of the second Fick's law of diffusion (Eq. 2), supposing that chlorides content at the concrete surface $\left(C_{s}\right)$ is constant with time, and apparent chloride diffusion coefficient $\left(D_{\text {app }}\right)$ does not vary with time and space (i.e. concrete is homogeneous):

$$
C_{x}=C_{S} \cdot\left(1-\operatorname{erf} \frac{x}{2 \sqrt{D_{\text {app }} t}}\right)
$$

where $C_{x}$ is the chloride content at the depth $x$ and $t$ is time [1].

Higher chlorides content was measured in concrete without inhibitor, while in the presence of organic inhibitors chloride penetration is reduced with time (Figure 4). A slight effect was also noticed in the presence of nitrite-based inhibitor (NIT). Elaboration of the data by means of Eq. 2 highlighted that the presence of organic inhibitors reduces the apparent diffusion coefficient from 2 to 4 times the values obtained for reference concrete (Table 4). Maximum reduction occurs in specimens containing inhibitors OCIA-2 and OCIA-3. Similar effect have been reported in literature [11].

Inhibitors have a sort of "physical-barrier" effect: this is probably due to the formation of gel compounds among organic substances and cement paste that block the pores. From an electrochemical point of view, this effect cannot be considered a real 
inhibiting action; moreover similar or stronger effect can be obtained acting on concrete mixture proportion, reducing $\mathrm{W} / \mathrm{C}$ ratio or using pozzolanic or slag cements [1].
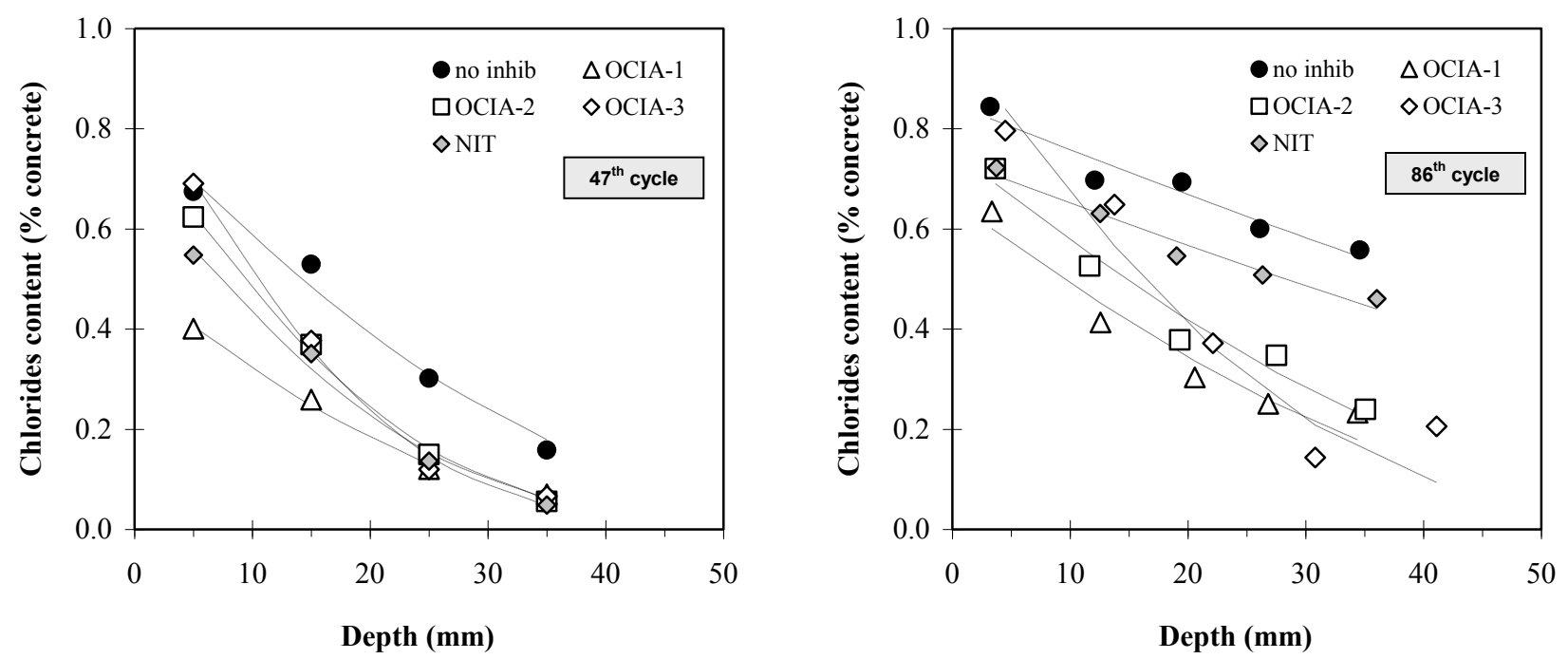

Figure 4. Total chloride penetration profiles for reinforced concrete (series B) [43].

Critical chloride threshold. Knowing the time of corrosion initiation and apparent diffusion coefficients, the critical chloride content at the rebar level $(x=20 \mathrm{~mm})$ can be estimated by means of second Fick's law analytical solution (Eq. 2) or graphically using the measured profiles. Results are summarized in Table 4.

The extrapolated data has to be carefully analysed, since the diffusion coefficient is not constant with time (see Table 4), as requested to use the analytical solution of Fick's law. Besides, values are related to the described experimental conditions, so they should not be considered as absolute values, but used only for comparison purposes.

In the absence of inhibitor, estimated critical chloride content is in the range 0.5$1.2 \%$ with respect to cement weight: those values are in agreement with literature, at least the minimum ones [1].

In our tests, organic inhibitors OCIA-1 and OCIA-3 provide a significant increase in critical chloride content: both minimum and maximum values are doubled with respect to reference condition. Inhibitor OCIA-2 does not offer any significant influence. In the same experimental conditions two organic compounds (DMEA and benzoate) show lower effect, in agreement with results reported by Elsener [11] that it is necessary the presence of both compounds to provide a significant effect. Results of series A (not shown here) confirmed the best performance of inhibitor OCIA-1, while the performance of the other two inhibitors was reversed $v s$ series B.

The inhibitive effect of inhibitor OCIA-1 is also confirmed by results obtained in a parallel series of tests in which chlorides were directly added in the mixture of the concrete in concentration $1.2 \%$ with respect cement weight: all carbon steel rebars were in passive condition even after 5 years [41]. In presence of higher chloride content added to the mix 
(1.5-2.5\% by cement weight) in series A concrete the performance of organic inhibitors resulted poor [40].

Calcium nitrite-based inhibitor (NIT) must be analysed separately; more literature data are available on its inhibiting action, suggesting that the corrosion inhibitor is effective if the molar ratio $\left[\mathrm{NO}_{2}^{-}\right] /\left[\mathrm{Cl}^{-}\right]$is higher than $0.5-0.6$ [11]. Tests results seem to be in accordance with literature: considering inhibitor dosage $\left(7.5 \mathrm{~L} / \mathrm{m}^{3}\right.$ for series A and $10 \mathrm{~L} / \mathrm{m}^{3}$ for series B) and the obtained critical chloride content (Table 4), the estimated molar ratio $\left[\mathrm{NO}_{2}^{-}\right] /\left[\mathrm{Cl}^{-}\right]$is in the range $0.42-0.51$. The reliability of the critical molar ratio was also confirmed by tests performed on concrete specimens cast with chloride $0.8 \%$ and $1.2 \%$ by cement weight [40]: after five year tests rebar are still in passive condition, and the calculated molar ratio is 0.55 and 0.37 , respectively; for concrete cast with higher chloride content and lower amount of molar ratio $\left[\mathrm{NO}_{2}^{-}\right] /\left[\mathrm{Cl}^{-}\right]$rebars were in active conditions.

Corrosion rate. In this analysis only concrete series A is reported, but the results in series B are not very different. Only nitrite based inhibitor in the higher dosage lowers corrosion rate (Fig. 5). Lowest penetration rate, referred to corroded area, were measured for nitrite based inhibitor with high dosage and inhibitor OCIA-1: nevertheless, mean penetration rate referred to corroded area is higher than $10 \mu \mathrm{m} /$ year (Fig. 5), so corrosion cannot be considered negligible.

Also in specimens subjected to chlorides penetration, a lowering of corrosion rate after corrosion initiation was observed only in the presence of nitrite based inhibitor. In the other cases, corrosion rates range between 4.5 and $12 \mu \mathrm{m} /$ year [40].

It should be underlined that for chloride induced corrosion the world-wide approach is to consider the service life of a concrete structure equal to the initiation time, so the effect of corrosion inhibitors on propagation time (corrosion rate) seem to be less important.
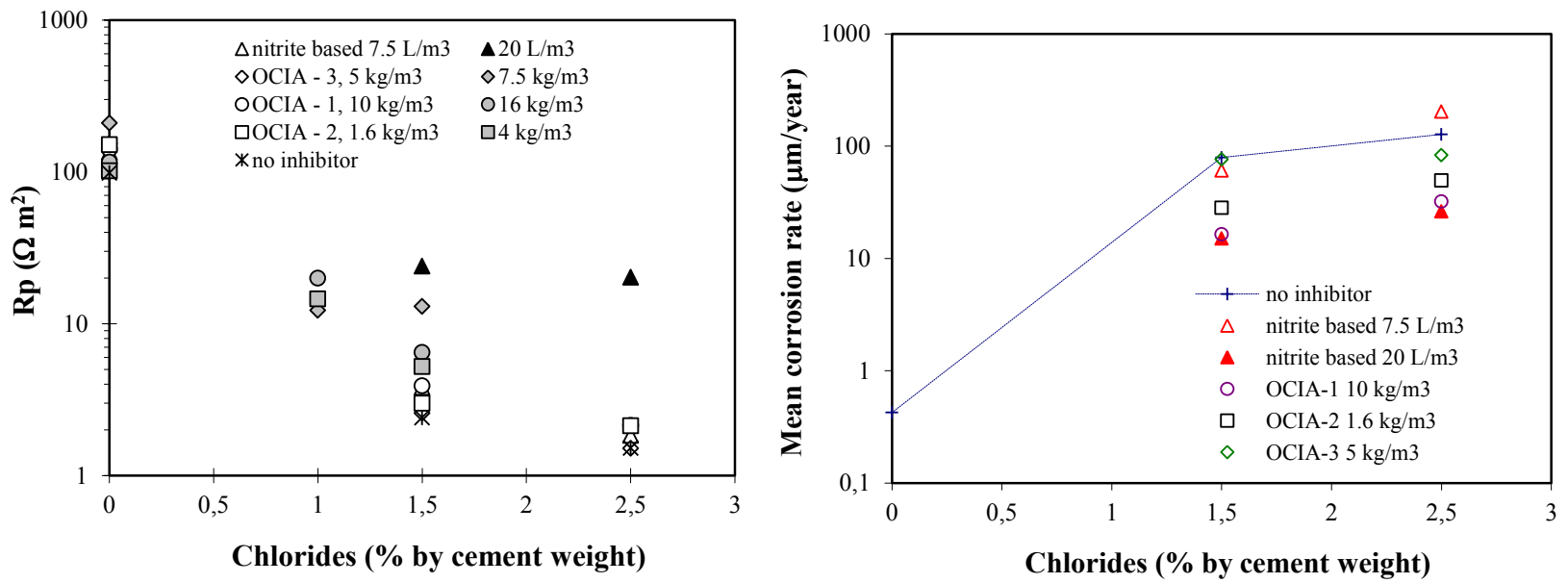

Figure 5. LPR of rebar in concrete specimens with admixed chlorides: mean values between 100 and 500 days of atmospheric exposure (left); mean corrosion rate of carbon steel rebars embedded in chlorides containing concrete after 3 years exposure, calculated by weight loss and referred to the real corroded area (right) [40]. 


\subsection{Commercial corrosion inhibitors - admixed-Carbonation induced corrosion}

Influence on carbonation depth. Carbonation penetration was detected by means of phenolphthalein tests on cubic specimens after accelerated carbonation. Carbonation coefficients $\mathrm{k}$ were estimated interpolating the experimental data. Results show that the commercial corrosion inhibitors do not reduce carbonation penetration; only in concrete with organic inhibitor OCIA-1 carbonation coefficient is slightly lower (about 7.5\%) with respect to the reference concrete, even if this reduction is not very significant.

Influence on corrosion rate. Rebars corrosion rate ( $\mu \mathrm{m} / \mathrm{year})$ calculated by LPR measurements in carbonated concrete specimens is reported in Fig. 6. Corrosion inhibitors seem not to influence corrosion rate with respect to the value measured in concrete without inhibitor: moreover mean and maximum values are higher than $2 \mu \mathrm{m} / \mathrm{year}$, so corrosion is not negligible. Inhibitor effectiveness has been evaluated in terms of efficiency $(\eta)$, defined as the percentage reduction of corrosion rate due to the presence of a corrosion inhibitor:

$$
\eta=\frac{i_{\text {corr }}^{*}-i_{\text {corr }}}{i_{\text {corr }}^{*}}
$$

where $i_{\text {corr }}$ and $i_{\text {corr }}^{*}$ are the mean values of corrosion rate with and without inhibitor respectively.

It is worth noticing that only inhibitors OCIA-2 and OCIA-3 present an efficiency of about $25 \%$, while this figure is $2 \%$ for OCIA-1 and so the inhibition action against carbonation induced corrosion is not good.

Nitrite dosage suggested by producers, that is in this case $1 \%$ by cement weight, is not adequate to reduce corrosion rate in carbonated concrete. This is in accordance with literature data that report as reference value a dosage close to $2-3 \%$, in order to reduce corrosion rate in carbonated concrete [54].

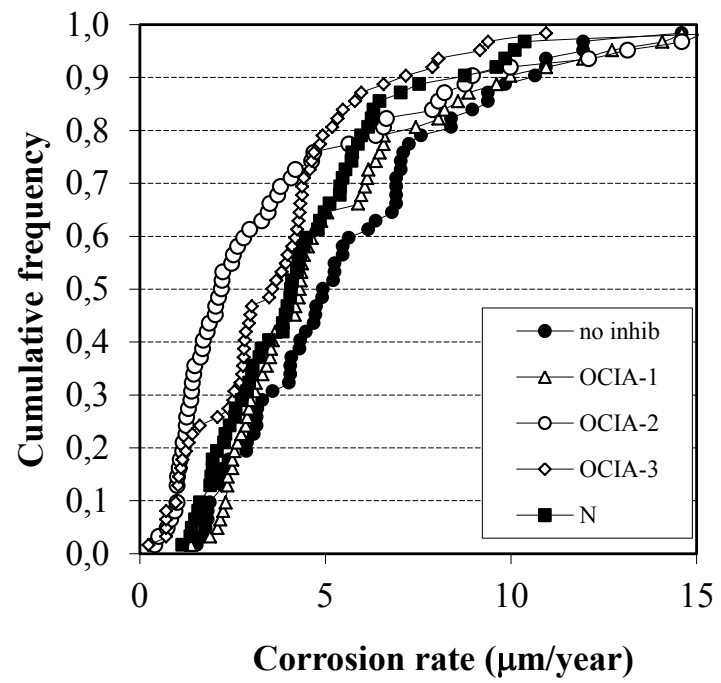

Figure 6. Cumulative frequency of corrosion rate in carbonated specimens containing commercial corrosion inhibitors [41]. 


\subsection{Migrating corrosion inhibitors - chloride induced corrosion}

Effect on initiation of corrosion. If migrating corrosion inhibitors are applied to concrete with passive rebars, they are able to delay the corrosion initiation, as shown in Figure 7 where the initiation of corrosion (ponding cycle) was detected. The best results were obtained in the case of migrating inhibitor MIG-2: the first rebar corroded at the $23^{\text {rd }}$ cycle, but one rebar is still in passive condition after 80 ponding cycles.

Figure 7 illustrates total chlorides profiles measured at 80th ponding cycle: migrating inhibitors reduce chlorides penetration into concrete. Apparent diffusion coefficient were determined as in par. 3.1. Diffusion coefficient is significantly reduced (one fifth) at long time after the application of the MCIs.
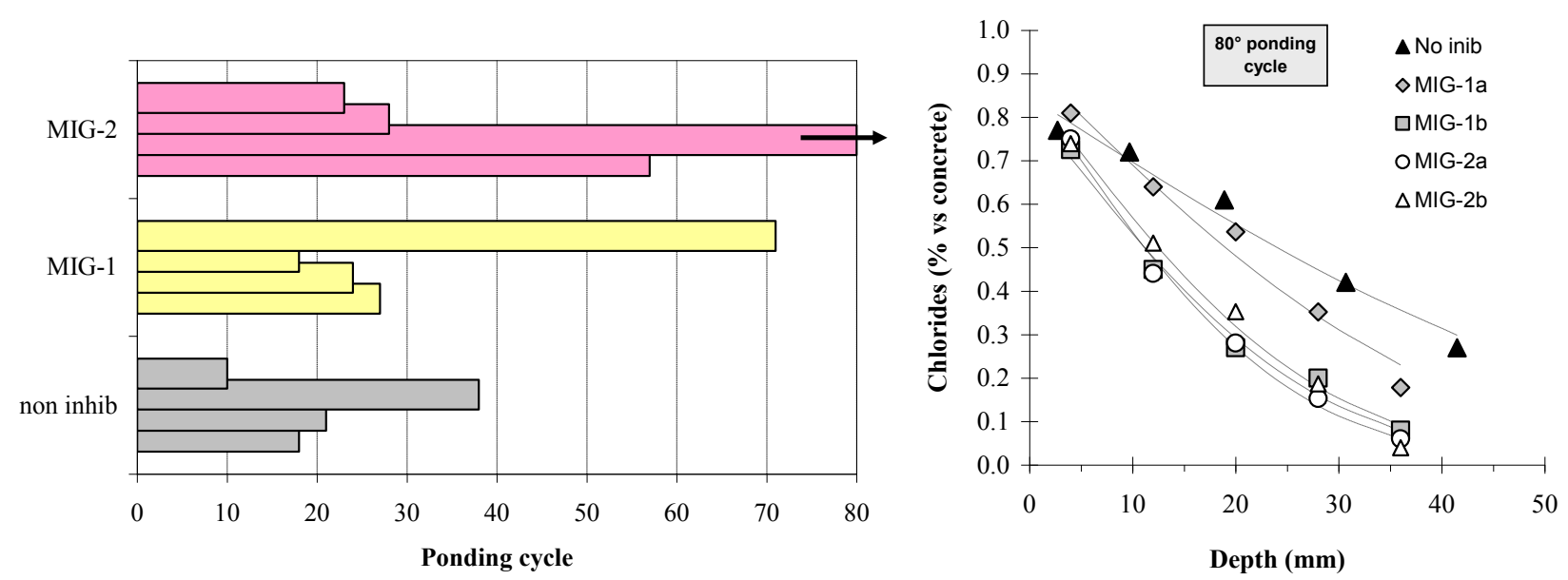

Figure 7. Time to corrosion for rebars in specimens subjected to chloride ponding (migration inhibitors applied before corrosion initiation) (left) total chloride content after 80 ponding cycles (right) [42].

Critical chloride threshold was evaluated as in par. 3.1 and resulted very similar in presence or absence of corrosion inhibitors: $0.21-0.27 \%$ by concrete weight (approximately $1.4-1.9 \%$ by cement weight). So the main effect is related to the decrease of diffusion coefficient.

Effect on propagation of corrosion. After corrosion initiation, no significant reduction of corrosion rate was measured by inhibitor's application, neither in the case of admixed chlorides, nor in the case of chlorides ponding. For example, Fig. 8 reports mean, maximum and minimum rebar corrosion rate measured in concrete containing chlorides $1.2 \%$ by cement weight before migrating inhibitors application and after the three applications. Corrosion rates are always higher than $1 \mu \mathrm{m} / \mathrm{year}$, considered the threshold values above which corrosion is negligible: migrating corrosion inhibitors are not effective in reducing corrosion rate. Similar results were obtained in the case of concrete exposed to chlorides ponding: corrosion rate remains quite high, more than $10 \mu \mathrm{m} /$ year (Fig. 8 right); even the continuous application for 250 days of $1 \mathrm{~L}$ of MCIs after the end of chlorides penetration did not reduce the corrosion rate. 

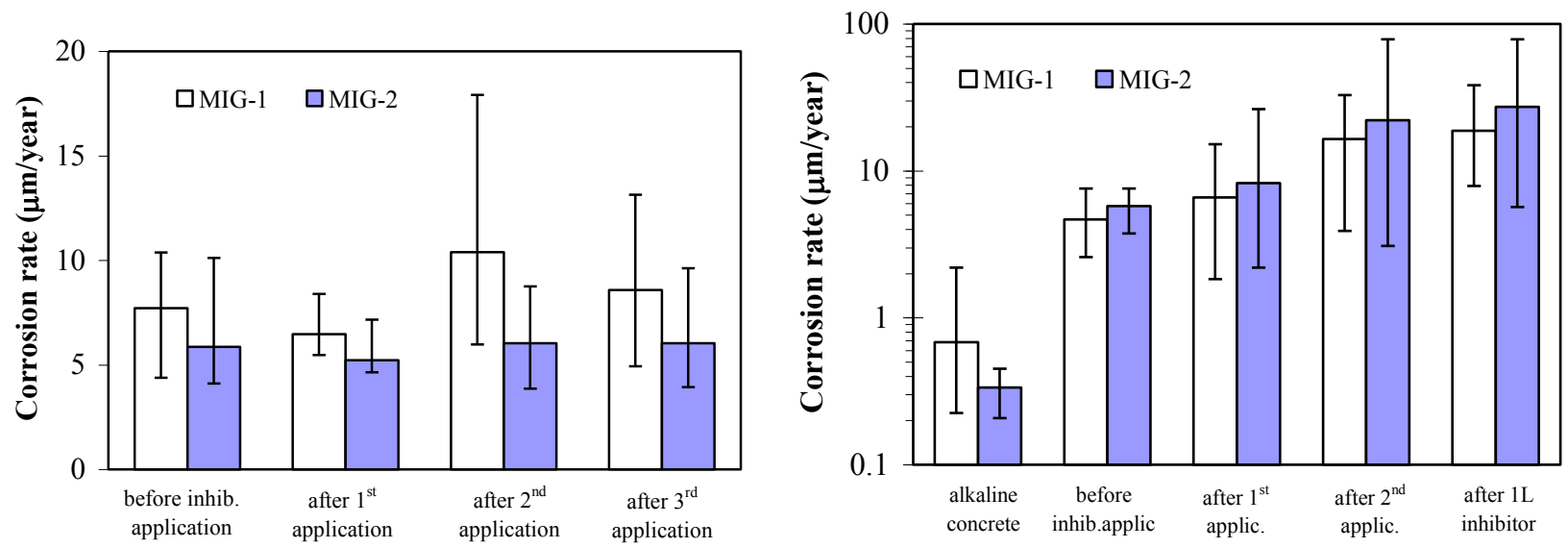

Figure 8. Corrosion rate measured on rebars in concrete with $1.2 \%$ chloride vs cement weight (left) and in concrete subjected to ponding (right); application of migrating corrosion inhibitor after corrosion initiation [42].

\subsection{Migrating corrosion inhibitors - carbonation induced corrosion}

After carbonation of concrete mean corrosion rate increase from $1 \mu \mathrm{m} /$ year (passive condition) to values in the range of 7-12 $\mu \mathrm{m} /$ year (active condition). After the application of MIG-1 and MIG-2 a decrease of corrosion rate was observed. Nevertheless, the residual corrosion rate is not negligible; after the 2nd application (Fig. 9) it is still much higher than $1 \mu \mathrm{m} /$ year, reaching maximum values close to $10-15 \mu \mathrm{m} /$ year. Moreover the results are not always reproducible. These results are in agreement with few available literature data on the efficiency of MCIs in carbonated concrete [31]; according to this work, no effect was noticed on corrosion rate after one year exposure. In the case of carbonation, according to literature, inhibitor penetration is effective only after several weeks and in dried specimens [30]. Probably, in the considered experimental conditions, inhibitors did not reach rebar level and the effect on corrosion rate can be due to change in concrete resistivity.

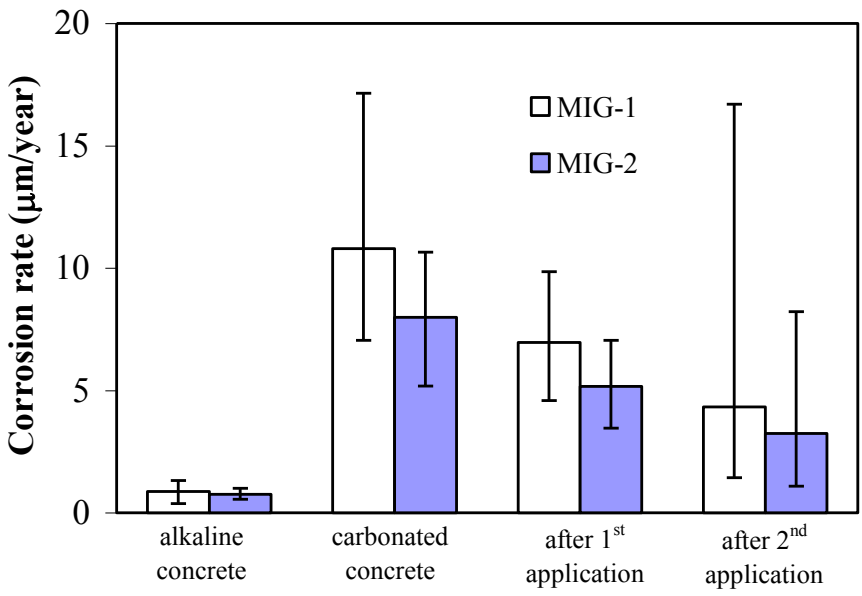

Figure 9. Corrosion rate measured on rebars in carbonated concrete (migrating corrosion inhibitor was applied after initiation of corrosion) [42]. 


\subsection{Transport of migrating corrosion inhibitors}

To avoid steel corrosion, migrating inhibitors must penetrate into cover concrete and reach the reinforcements in an adequate concentration to adsorb on steel surface and inhibit anodic and/or cathodic processes.

On the basis of our experimental results, the main transport mechanism into concrete of a liquid migrating corrosion inhibitor is capillary absorption. The rate of absorption is a function of the concrete porosity, fluid properties (density, surface tension, viscosity) and of the interaction between surface and liquid (contact angle).

The studied inhibitor (MIG-1) is amine based and contains inorganic phosphorous compounds; liquid inhibitor density is $1.15 \mathrm{~g} \mathrm{~cm}^{-3}$ and it is comparable to distilled water density. Inhibitor viscosity is higher than distilled water one.

In our tests it has been demonstrated that inhibitor penetration is very low (capillary coefficient $S$ is lower than the one obtained for water, the penetration is limited only to the first $20 \mathrm{~mm}$ of depth into concrete after long time), two main reasons may be ascribed: the higher inhibitor viscosity and, mainly, the presence of a chemo-physical interaction of the inhibitor mixture with the concrete pores surface, that lead to the formation of complex compounds that block the concrete porosity. This can also explain the reduction of the capillary absorption coefficient with time; inhibitor absorption on capillary pores surface lead to a decrease of the concrete porosity with an absorption coefficient reduction.

Nevertheless, concrete porosity reduction can also decrease aggressive species penetration with an increment of corrosion initiation time [1]. This is in agreement with the results presented in Figure 7 (par. 3.3) where it was found that MIG-1 inhibitor is able to increase the time-to-corrosion. This increment is probably related to a blocking effect due to the decrease of concrete porosity, and only in part to a physical and/or chemical action of the inhibitor at steel surface.

On the other hand, even if such inhibitors were able to reach the rebars level, the effectiveness of amines and alkanolamines based products, when they are used as admixed inhibitors is not always reproducible, as shown in par. 3.1 and 3.2 and reported in literature [11].

\subsection{Organic substances}

Screening of the best substances. More than 80 organic substances were tested as candidate inhibitors for reinforcement corrosion in chlorides containing concrete. Amines and alkanolamines are the basis for most of the commercial corrosion inhibitors. They are organic compounds containing a nitrogen atom with a lone pair, responsible of the adsorption on the metal surface. Organic carboxylates are characterised by the presence of a $-\mathrm{COOH}$ group. They are proton donors and are considered Bronsted-Lowry acids. At $\mathrm{pH} 12.6$ they are in ionic form. Carboxylate adsorption on the metal surface occurs through the delocalised electrical charge on the two oxygen atoms of the carboxylic group. Amino acids contain both aminic and carboxylic groups. 
The inhibition effectiveness is presented and discussed on the basis of Pedeferri's type diagrams, where pitting potential, $E_{\text {pit }}$, is plotted as a function of chlorides concentration [5-7]. Results are also compared to those obtained in alkaline solution without organic substances $\left(\mathrm{NaOH} 0.01 \mathrm{~mol} / \mathrm{L}+\mathrm{Ca}(\mathrm{OH})_{2}\right.$ sat, $\mathrm{pH}$ 12.6) and the same alkaline solution with $0.1 \mathrm{~mol} / \mathrm{L}$ sodium nitrite.

The effectiveness of the candidate inhibitor has been assessed on the basis of the value of breakdown (pitting) potential: absolute value should be higher than $50 \mathrm{mV} \mathrm{SCE}$, that correspond to free corrosion potential of steel reinforcement in atmospherically exposed concrete structures, and there should be an improvement with respect to the value measured in the control solution (target value was arbitrarily fixed about $300 \mathrm{mV}$ difference).

In solution without inhibitors, pitting potential decreased from $-200 \mathrm{mV}$ to $-500 \mathrm{mV}$ SCE as chlorides concentration increased from $0.1 \mathrm{~mol} / \mathrm{L}$ to $1 \mathrm{~mol} / \mathrm{L}$. In the presence of sodium nitrite pitting potential increase of about $600 \mathrm{mV}$ for each chloride content (Fig. 10). The different compounds showed these performances:

1. amines showed poor inhibition effect, with very scattered result when their volatility increased

2. amino acids showed some inhibition effect

3. carboxylate substances, especially poly-carboxylates, showed very good inhibition effectiveness, making them the most promising candidates among the tested substances.

As far as carboxylate substances, a strong link was found between inhibiting properties and molecular structure. The inhibition action is influenced by one or more of these factors:

- electron-attractor or electron-donor effect: electron-donor substituent, that gives up electrons, promotes the adsorption process through the negative charge localisation on oxygen and on carboxylic group (adsorption is a combination of inductive and resonance effect on electron density of the molecule); on the opposite, high electronegative substituent tends to be electron-attractor then weakening adsorption process being electrons not available for it

- electrostatic effect: adsorbed molecules with a negatively charged substituent or a lone pair electrons develop a repulsive action towards chloride ions, avoiding chloride to be in contact with the carbon steel passive layer

- steric effect: alkyl chain or voluminous substituent groups form a sort physical barrier that blocks or delay chloride arrival to the metal surface

- lateral interaction effect: some repulsion effect between adsorbed molecules is possible, because of the presence of highly polar group.

Effect on chloride penetration. Diffusion coefficients decrease with time as results of the continuous cement hydration that lead to a concrete porosity reduction. In any case, all 
tested organic substances did not show any influence on the diffusion coefficient except the specimen with glutamate in which formation of cracks lead to an enhancement in transport.

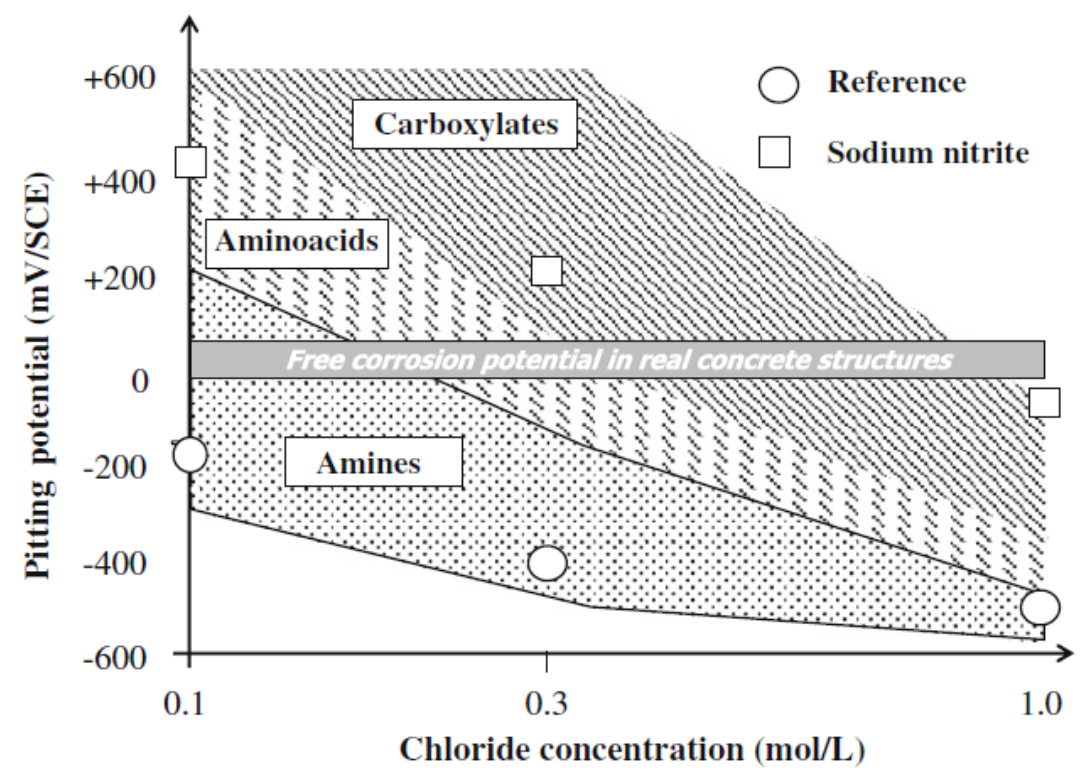

Figure 10. Pitting potential range obtained for amines, amino acids and carboxylates [46].

Effect on critical chloride threshold. In the reference solution (without candidate inhibitors), as soon as chlorides reached $0.1 \mathrm{~mol} / \mathrm{L}$ all specimens corroded, i.e. critical chlorides concentration for carbon steel in alkaline solution ranges from 0.05 to $0.1 \mathrm{~mol} / \mathrm{L}$, that corresponds to a $\left[\mathrm{Cl}^{-}\right] /\left[\mathrm{OH}^{-}\right]$molar ratio in the range of $1.2-2.5$. In the presence of nitrite $0.1 \mathrm{~mol} / \mathrm{L}$, localised corrosion occurred for a chloride content in the range of $0.5-$ $0.8 \mathrm{~mol} / \mathrm{L}$, that is one order of magnitude higher: critical was about 0.2 (Figure 11).

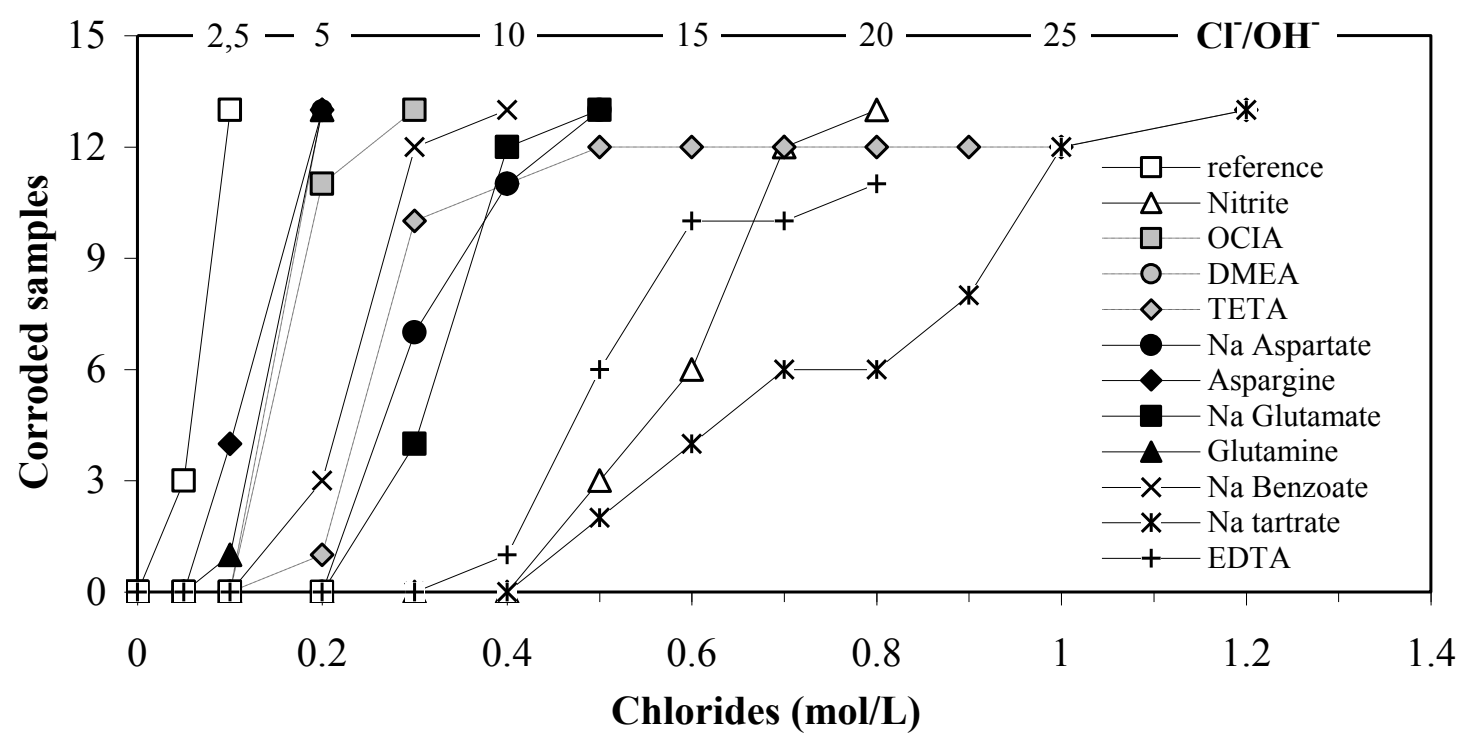

Figure 11. Potentiostatic tests: corroded samples at increasing chlorides concentration in the presence of organic substances in simulated pore solution [47]. 
The presence of amines show different performance: DMEA slightly improved critical chloride content to $0.2 \mathrm{~mol} / \mathrm{L}$ while TETA improved much more to $0.2-0.5 \mathrm{~mol} / \mathrm{L}$ (with one specimen without corrosion at more than $1 \mathrm{~mol} / \mathrm{L}$ ). Some amino acids performed well: sodium aspartate and sodium glutamate enhance critical chlorides content up to $0.4 \mathrm{~mol} / \mathrm{L}$. The presence of carboxylate compounds delayed corrosion occurrence more than the other organic substances: critical chlorides concentration ranges between $0.2-$ $0.4 \mathrm{~mol} / \mathrm{L}$ (benzoate) to $0.4-1 \mathrm{~mol} / \mathrm{L}$ (tartrate). These results are in close agreement with the screening tests (Figure 11).

Since polarisation can alter adsorption of inhibitors, free corrosion tests were performed too: steel samples in solution with amines DMEA and TETA showed corrosion with a chloride content of $0.05 \mathrm{~mol} / \mathrm{L}$, few days later than the samples in the reference solution. Amino acids increased critical chlorides content up to $0.1-0.2 \mathrm{~mol} / \mathrm{L}$ with the exception of aspargine and glutamine that performed similarly to the reference solution. The effect of carboxylate compounds is slightly better than the other substances, but results are not so promising if compared to those obtained in potentiostatic tests, in particular for sodium tartrate. Only EDTA showed a significant increase in critical chlorides content $(0.3 \mathrm{~mol} / \mathrm{L})$. It is worth noticing that in these tests, on the contrary of potentiostatic ones, corrosion started under the self-adhesive tape.

Critical chloride content in concrete was estimated as before (par. 3.1): in concrete without inhibitors is $1.3 \%$ by cement weight, higher than $0.4-1 \%$, typical range for carbon steel in alkaline concrete [1]; due to that, the critical chlorides threshold obtained with organic compounds have to be compared only with the results obtained in these experiments.

Among the amino-carboxylates, the higher increase is obtained with AMAC 4 (Glutamine) with a critical chlorides threshold of about 2.0\%; sodium glutamate confirms its worse behaviour (Table 5). In the presence of carboxylate compounds, only sodium benzoate (CARB 1) and EDTA (CARB 3) show a slight improvement with respect the reference conditions, while tartrate showed only little improvement vs reference solution. Best results are obtained with amines: in the case of TETA (AM 2), the critical chlorides threshold is twice the reference value and with DMEA is 50\% higher than the value of reference condition.

In chlorides containing concrete $(0.8 \%$ and $1.2 \%$ by cement weight) after four years of atmospheric exposure: $a$ ) the tested organic substances had a good inhibiting effect in the case of chlorides $0.8 \%$ (corrosion rate $<2 \mu \mathrm{m} / \mathrm{y}$ ), although this chloride content is in the range of critical values without inhibitors; $b$ ) only the organic compounds TETA, glutamine and sodium tartrate are effective also in concrete with chlorides $1.2 \%$ by cement weight. 
Table 5. Summary of the results of the ponding test on concrete series $C$ (w/c ratio 0.6) [47].

\begin{tabular}{lccc}
\hline & $\begin{array}{c}\text { Initiation } \\
\text { (cycle) }\end{array}$ & $\begin{array}{c}\mathbf{D} \\
\left(\mathbf{1 0}^{-8} \mathbf{c m}^{\mathbf{2}} / \mathbf{s}\right)\end{array}$ & $\begin{array}{c}\mathbf{C r i t i c a l ~} \mathbf{~}^{-} \\
(\mathbf{\%} \mathbf{w t} \boldsymbol{~} \boldsymbol{s} \text { cement) }\end{array}$ \\
\hline No inhibitor & $32-35$ & $4.2-6.5$ & $1.3-1.6 \%$ \\
AM 1 (DMEA) & $38-66$ & $4.3-7.4$ & $2.3-2.5 \%$ \\
AM2 (TETA) & $77-78$ & $4.8-7.3$ & $2.7-3.2 \%$ \\
AMAC 1 (aspartate) & $42-49$ & $4.4-8.9$ & $1.3-1.6 \%$ \\
AMAC 2 (aspargine) & $52-65$ & $2.2-6.7$ & $1.4-1.6 \%$ \\
AMAC3 (glutamate) & 5 & $7.8-12.5$ & $0.6-0.7 \%$ \\
AMAC 4 (glutamine) & $65-77$ & $2.7-6.5$ & $2-2.2 \%$ \\
CARB 1 (benzoate) & $42-44$ & $2.4-5.6$ & $1.8-2.0 \%$ \\
CARB 2 (tartrate) & $46-57$ & $2.7-5.7$ & $1.5-1.6 \%$ \\
CARB 3 (EDTA) & $46-52$ & $2.6-7$ & $1.8-2.1 \%$ \\
\hline
\end{tabular}

Inhibition effectiveness. In Table 6 all the main obtained results are summarised. For each experimentation a ranking ( 1 is the best, 10 the worst) has been evaluated as follow:

- solution tests (potentiostatic and free corrosion): the chlorides content ( $\mathrm{mol} / \mathrm{L})$ in correspondence to corrosion initiation has been reported. The higher the chlorides content of the first corroded sample, the higher the ranking; in the case of the same value, the higher the maximum chlorides content, the higher the effectiveness;

- chlorides containing concrete: both maximum and mean corrosion rate have been taken into account; if rebar corrosion rate is lower than $2 \mu \mathrm{m} / \mathrm{y}$, the maximum evaluation (ranking $=1$ ) has been attributed;

- concrete ponding test: the cycle in correspondence of initiation of corrosion on the first rebar has been considered.

In the last row of Table 3 the mean ranking position has been evaluated. Obviously, the lower the values, the higher the inhibitive effect. All the analysed organic compounds lead to an inhibition effect with respect to the condition without any added compound.. The best effectiveness has been observed in the presence of carboxylate compound sodium tartrate (ranking 2.8) and EDTA (3.8). Also amine TETA (ranking 3.8) show a good inhibition action. It is important to remark that some differences are obtained between solution and concrete tests results. Glutamate showed poor performance in concrete tests due to formation of cracks. Tartrate showed reduced effectiveness in free corrosion solution and poor performance in concrete subjected to chloride ponding: in this last case probably the performance is related to the lower content $(0.1 \% v s$ cement weight, $1 \%$ for the other compounds) added to the mix. 
Table 6. Inhibition performance.

\begin{tabular}{|c|c|c|c|c|c|c|c|c|c|c|}
\hline \multirow[b]{2}{*}{ Test $^{\S}$} & \multirow{2}{*}{ ref } & \multicolumn{2}{|c|}{$\mathbf{A M}$} & \multicolumn{4}{|c|}{ AMAC } & \multicolumn{3}{|c|}{ CARB } \\
\hline & & 1 & 2 & 1 & 2 & 3 & 4 & 1 & 2 & 3 \\
\hline \multirow{3}{*}{ S1 } & 0.05 & 0.2 & 0.2 & $\begin{array}{l}0.3 \\
0.5\end{array}$ & 0.1 & 0.3 & 0.1 & 0.2 & 0.5 & 0.4 \\
\hline & & & & & 0.2 & 0.5 & 0.2 & & & \\
\hline & 10 & 7 & 5 & 4 & 9 & 3 & 8 & 6 & 1 & 2 \\
\hline \multirow{2}{*}{ S2 } & 0.05 & 0.05 & 0.05 & 0.2 & 0.05 & 0.1 & 0.05 & 0.1 & 0.2 & 0.3 \\
\hline & 10 & 7 & 8 & 2 & 9 & 4 & 6 & 5 & 3 & 1 \\
\hline \multirow{3}{*}{$\begin{array}{l}\text { C1 max } \\
\text { C1 mean }\end{array}$} & 9.9 & 5.6 & 1.9 & 9.2 & 5.2 & 3.5 & 1.1 & 5.8 & 2.3 & 7.7 \\
\hline & 4.38 & 1.8 & 0.6 & 4.7 & 2.3 & 1 & 0.5 & 2.2 & 0.9 & 2.6 \\
\hline & 9 & 5 & 1 & 10 & 7 & 4 & 1 & 6 & 3 & 8 \\
\hline \multirow{2}{*}{$\mathrm{C} 2$} & 32 & 38 & 77 & 29 & 52 & n.a. & 65 & 42 & 46 & 46 \\
\hline & 9 & 8 & 1 & 10 & 5 & 10 & 2 & 7 & 6 & 6 \\
\hline rank & 9.3 & 6.5 & 3.8 & 6.3 & 7 & 5.3 & 4.3 & 5.8 & 2.8 & 3.8 \\
\hline
\end{tabular}

${ }^{\S} \underline{\mathrm{S} 1}$ : potentiostatic test (critical chlorides content $\left.-\mathrm{mol} / \mathrm{L}\right) ; \underline{\mathrm{S} 2}$ : free corrosion test (critical chlorides content $-\mathrm{mol} / \mathrm{L}$ ); $\mathrm{C} 1$ : concrete with $\mathrm{Cl}^{-} 1.2 \%$ (maximum and medium corrosion rate $-\mu \mathrm{m} / \mathrm{y}$ ); C2: concrete subjected to ponding (initiation time).

\section{Conclusions}

Organic commercial admixed corrosion inhibitors (OCIA) delayed the occurrence of chloride induced corrosion. This result can be related to two effects:

o reduction of the rate of chloride transport into concrete: from an electrochemical point of view, this effect is not a real inhibitive action, but a sort of "physical barrier" effect;

$\circ$ two of these admixtures (OCIA-1 and OCIA-3) provide an increase of the critical chloride threshold with respect to rebars in concrete without admixed inhibitors.

Commercial migrating corrosion inhibitors (MCI):

$\circ$ are able to delay time-to-corrosion of passive rebars in specimens subjected to chlorides ponding; this effect is mainly related to the reduction of chlorides diffusion coefficient;

$\circ$ don't show any appreciable reduction of corrosion rate in chlorides contaminated concrete if they are applied after corrosion initiation;

o can reduce the corrosion rate in carbonated concrete, nevertheless the efficiency is low and residual corrosion rate is not negligible;

o can penetrate into concrete mainly through capillary sorption, slower than water; penetration depth is limited to $20 \mathrm{~mm}$; migrating organic inhibitor interacts with the 
constituents of the cement paste, with a reduction of the concrete porosity; this effect can reduce the permeability of aggressive agents too.

The results obtained with nitrite-based inhibitor confirm literature data: the inhibitor is effective if the molar ratio $\left[\mathrm{NO}_{2}^{-}\right] /\left[\mathrm{Cl}^{-}\right]$is higher than $0.5-0.6$; in carbonated concrete, due to insufficient amount of inhibitor, no significant effect has been observed on corrosion rate.

Organic substances:

○ compounds containing carboxylic group showed the best results in potentiodynamic or potentiostatic polarisation tests in solution: pitting potential, time-to-corrosion and critical chloride content are similar to those obtained with sodium nitrite;

$\circ$ in concrete tests, one amine (TETA) and one amino acid (glutamine) showed good performance increasing the critical chlorides threshold with respect to the reference condition.

As far as carboxylate substances, a strong link was found between inhibiting properties and molecular structure: electron-attractor or electron-donor substituents, electrostatic effect, steric effect and lateral interaction effect have proven to be significant.

\section{Acknowledgements}

A special thank to Prof. Pietro Pedeferri, maestro and friend, who actively participated in this research in the selection of the candidate corrosion inhibitors, and to whom this paper is dedicated.

\section{References}

1. L. Bertolini, B. Elsener, P. Pedeferri and R. Polder, Corrosion of steel in concrete: prevention, diagnosis, repair, Wiley, Weinheim, 2004.

2. C. Alonso, M. Castellote and A. Andrade, Electrochim. Acta, 2002, 47, 3469.

3. G. K. Glass and N. R. Buenfeld, Corros. Sci., 2000, 42, 923.

4. U. Angst, B. Elsener, K. C. Larsen and Ø. Vennesland, Cement and Concrete Research 2009, 39, 1122.

5. P. Pedeferri, L'Edilizia, 1993, 10, 69 (in Italian).

6. L. Bertolini, F. Bolzoni, T. Pastore and P. Pedeferri, in Corrosion and Corrosion protection of steel in concrete, Ed. N. Swamy, Sheffield Academic Press, 1994, p. 1376.

7. P. Pedeferri, Construction and building materials, 1996, 10, 5, 391.

8. Yu. I. Kuznetsov, Int. J. Corros. Scale Inhib., 2012, 1, 3. doi: 10.17675/2305-68942012-1-1-003-015

9. T. Abohalkuma, F. Shawish and J. Telegdi, Int. J. Corros. Scale Inhib., 2014, 3, 151. doi: $10.17675 / 2305-6894-2014-3-3-151-159$

10. N. N. Andreev, O. A. Goncharova and S. S. Vesely, Int. J. Corros. Scale Inhib, 2013, 2, no. 3, 162. doi: $10.17675 / 2305-6894-2013-2-3-162-193$ 
11. B. Elsener, Corrosion inhibitors for steel in concrete - State of the art report, EFC Publications, Number 35, 2001.

12. C. L. Page, in: Proceedings of the ninth European symposium on corrosion inhibitors, 2000, University of Ferrara (Italy), p. 261.

13. T. A. Soylev and M. G. Richardson, Construction and Building Materials, 2008, 22, 609.

14. A. M. Rosenberg, J. M. Gaidis, T. G. Kossivas and R. W. Previte, in: Chloride corrosion of steel in concrete, Eds. D. E. Tonini and S. W. Dean Jr., ASTM STP 629. American Society for Testing and Materials, 1977, p. 89.

15. C. Andrade, C. Alonso and J. A. Gonzalez, Cement, Concrete and Aggregates, 1986, 8, 2,110 .

16. N. S. Berke, Mater. Perform., 1989, 10, 41.

17. J. M. Gaidis, Cement and Concrete Composites, 2004, 26, 181.

18. K. J. Ann, H. S. Jung, H. S. Kim, S. S. Kim and H. Y. Moon, Cement and Concrete Research, 2006, 26, 530.

19. S. N. Alekseev, V. B. Ratinov, N. K. Rozental and N. M. Kashurnikov, Ingibitory korrozii stali $v$ zhelezobetonnykh konstruktsiyakh (Steel corrosion inhibitors in reinforced concrete structures), Moscow, Stroiizdat, 1985 (in Russian).

20. M. Collepardi, R. Fratesi, G. Moriconi, C. Corradetti and L. Coppola, International RILEM symposium on admixtures for concrete, Barcellona, Ed. Vazquez, Chapman and Hall, London, UK, 1990, p. 279.

21. R. Fratesi, G. Moriconi and S. Simoncini, Giornate nazionali sulla corrosione $e$ protezione, AIM, 1994, Milan, p. 39 (in Italian).

22. E. Pazini, S. Leao and G. Estefani, proc. NACE Conference: Latin-American Congress, Cancun, Mexico, 1998, p. 134.

23. C. K. Nmai, S. A. Farrington and G. S. Bobrowsky, Concrete International, 1992, 14, 45.

24. U. Mäder, Concrete, 1999, 9, 215.

25. D. Bjegovic and B. Miksic, Mater. Perform., 1999, 9, 52.

26. L. Mechmeche, L. Dhouibi, M. Ben Ouezdou, E. Triki and F. Zucchi, Cement and Concrete Composites, 2007, 29, 365.

27. R. J. Kessler, R. G. Powers, M. A. Paredes, A. A. Sagués and Y. P. Virmani, proc. Corrosion/NACE'07, Houston TX, 2007, paper 293.

28. C. Andrade, C. Alonso, M. Acha and B. Malric, Cement and Concrete Research, 1996, 26, 405.

29. V. T. Ngala, C. L. Page and M. M. Page, Corros. Sci., 2003, 45, 1523.

30. J. Tritthart, Cement and Concrete Research, 2003, 33, 829.

31. W. Morris and M. Vazquez, Cement and Concrete Research, 2002, 32, 259.

32. B. Elsener, M. Büchler, F. Stalder and H. Böhni, Corrosion, 2000, 56, 727.

33. A. Phanasgaonkar, M. Forsyth and B. Cherry, proc. of $13^{\text {th }}$ ICC, Melbourne, 1996, paper 178.

34. C. Monticelli, A. Frignani and G. Trabanelli, Cement and Concrete Research, 2000, 30, 635 . 
35. M. Cabrini, S. Lorenzi and T. Pastore, Electrochim. Acta, 2014, 124, 156.

36. C. Monticelli, A. Frignani, A. Balbo and F. Zucchi, Materials and Corrosion, 2011, 62, no. $2,178$.

37. N. N. Andreev, D. S. Bulgakov, I. A. Gedvillo, A. S. Zhmakina and S. S. Vesely, Int. J. Corros. Scale Inhib., 2014, 3, 238. doi: 10.17675/2305-6894-2014-3-4-238-245

38. N. N. Andreev and O. A. Goncharova, Protection of Metals, 2004, 40, no. 3, 257 (Translated from: Zashch. Met., 2004, 40, no. 3, p. 280).

39. E. V. Starovoitova, I. A. Gedvillo, A. S. Zhmakina and N. N. Andreev, Protection of Metals and Physical Chemistry of Surfaces, 2010, 46, no. 7, 793 (Translated from: Korroz.: Mater., Zashch., 2009, no. 6, 30).

40. M. Ormellese, M. Berra, F. Bolzoni and T. Pastore, Cement and Concrete Research, 2006, 36, 536.

41. F. Bolzoni, L. Coppola, S. Goidanich, L. Lazzari, M. Ormellese and MP. Pedeferri, Corros. Eng., Sci. Technol., 2004, 39, no. 3, 219.

42. F. Bolzoni, S. Goidanich, L. Lazzari and M. Ormellese, Corros. Eng., Sci. Technol., 2006, 41, no. 3, 212.

43. M. Ormellese, F. Bolzoni, L. Lazzari and P. Pedeferri, Materials and Corrosion, 2008, 59, no. 2,98 .

44. M. Ormellese, F. Bolzoni, S. Goidanich, MP. Pedeferri and A. Brenna, Corros. Eng., Sci. Technol., 2011, 46, no. 4, 334.

45. G. Rondelli, L. Lazzari, M. Ormellese, R. Novoa, E. Perez, in Passivation of metals and semiconductors, and properties of thin oxide layers, Eds. P. Marcus and V. Maurice, $1^{\text {st }}$ ed., Elsevier BV, Amsterdam, 2006, p. 709.

46. M. Ormellese, L. Lazzari, S. Goidanich, G. Fumagalli, A. Brenna, Corros. Sci., 2009, 51, 2959.

47. M. Ormellese, F. Bolzoni, L. Lazzari, A. Brenna and M. Pedeferri, Mater. Corros., 2011, 62, no. 2, 170.

48. M. Ormellese, E. A. Pérez, G. Raffaini, F. Ganazzoli and L. Lazzari, J. Mater. Sci. Eng., 2010, 4, no. 10, 66.

49. CEN ENV 197/1: Standard, Cement - Part 1: composition, specifications and conformity criteria for common cements, 2000.

50. ASTM G61-86 (reapproved 2009), Standard Test Method for conducting cyclic potentiodynamic polarization measurements for localised corrosion susceptibility of iron-, nickel-, or cobalt-based alloys, 2009.

51. ASTM C876-91, Standard test method for half-cell potential of reinforcing steel in concrete, 1991.

52. M. Stern and A. L. Geary, J. Electrochem. Soc., 1957, 104, 56.

53. C. Andrade and J. A. Gonzalez, Werkst. Korroz., 1978, 29, 516.

54. C. Alonso and C. Andrade, ACI Materials J., 1995, 3-4, 130. 